\title{
The lacunae of the EU legal system and the role of the Court of Justice of the EU: two selected examples
}

\author{
Florence Hartmann-Vareilles • Michele Messina
}

Published online: 1 June 2011

(C) ERA 2011

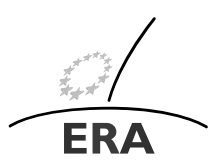

EUROPÄISCHE RECHTSAKADEMIE ACADEMY OF EUROPEAN LAW ACADEMIE DE DROIT EUROPEEN ACCADEMIA DI DIRITTO EUROPEO TRIER - TREVES - TREVIRI

\section{Introduction}

The process of harmonisation of different national rules, which characterised the early stages of the creation of the internal market as much as it does its present development, has often been affected by the inertia of the European Union legislator. The Court of Justice of the European Union has played a very important role in covering up this inertia, which concerns various and very distinct areas of law where political agreement is not always possible and the national relevant rules are by no means similar.

One of the significant examples of this is to be found in the field of intellectual property law, for which the EC Treaty did not contain any explicit powers for the adoption of legislation. Until the adoption of the Lisbon Treaty, secondary legislation could only be adopted on the basis mainly of Article 95 of the EC Treaty. Any legal measures had therefore to be justified by the objective of the achievement of the free movement of services or the establishment and the functioning of the internal market. This restriction of the scope of legislative power is one of the reasons why a two-speed legal system has been achieved at European Union level in the field of European Union intellectual property law. Whereas for example, in the field of

Authors of Sects. 2.

F. Hartmann-Vareilles, Head of Section ( $₫)$

European Business Law, Academy of European Law, Metzer Allee 4, 54295 Trier, Germany e-mail: fhartmann@era.int

Dr. M. Messina, Course Director

European Business Law Section, Academy of European Law, Metzer Allee 454295 Trier, Germany e-mail: mmessina@era.int 
trade mark law, a large consensus between the members states led to a high degree of harmonisation, the same level of harmonisation could not however be obtained in the field of copyright law, where the European Union legal system is still characterised to some extent by fragmentation into 27 national copyright regimes. This limited scope for adopting legislation at European Union level has been extended by Article 118 of the TEU (Treaty of the European Union) which allows for the adoption of measures "for the creation of European intellectual property rights to provide uniform protection of intellectual property rights throughout the Union and for the setting up of centralized Union-wide authorization, coordination and supervision arrangements".

However, the question of whether this provision will be used for adopting legislation in the field of copyright is still open. ${ }^{1}$ The attempt to unify European Union law effected by the European Court of Justice in that field is not to be underestimated. In the exercise its principal duty to interpret the provisions of secondary community copyright instruments, the European Court of Justice has shown its intention in recent case-law to reduce member states' margin of discretion by the adoption of common concepts applicable uniformly within the European Union.

The European Court of Justice has also contributed to the inclusion in the European Union legal system of those basic principles - mainly of a procedural nature which are guaranteed in the constitutions of the member states and which were not originally provided for either in the Treaties or in secondary legislation, due to the often exclusively economic scope of the provisions of both. In order to fill this lacuna, the European Court of Justice elaborated the general principles common to the law of the member states, as a result of a comparative analysis of European Union member states' legal systems. To achieve that, the European Court of Justice applied as many criteria as possible, sometimes without being excessively concerned about how effectively "common" the principles identified were. This lack of uniformity at member state level determined the European Court of Justice to affirm the evolutionary nature, at least potentially, of some of the EU general principles, like in the case of the legal professional privilege.

\section{The European Court of Justice and the autonomous concept of European Union law as a means to fill in the gap of lack of harmonisation: recent example in the field of copyright law}

In the field of copyright law, only a limited acquis communautaire has been achieved to date. Directives have mainly been adopted with respect to sector-specific controversial matters like computer software, ${ }^{2}$ databases ${ }^{3}$ or satellite and cable broadcasting. ${ }^{4}$

\footnotetext{
${ }^{1}$ This argument is put forward by Walter and von Lewinski [3], p. 13.

${ }^{2}$ Council Directive 91/250/EEC of 14 May 1991 on the legal protection of computer programs, O.J. 1991, L 122/42-46.

${ }^{3}$ Directive 96/9/EC of the European Parliament and of the Council of 11 March 1996 on the legal protection of databases, O.J. 1996, L 77/20-28.

${ }^{4}$ Council Directive 93/837EEC of 27 September 1993 on the coordination of certain rules concerning copyright and rights related to copyright applicable to satellite broadcasting and cable retransmission, O.J. 1993, L 248/15 and seq.
} 
If the seven directives adopted to date have removed the major disparities between the laws of the member states, they did not concern the main barrier to the creation of an internal market in products and creativity - viz., the territorial nature of economic rights. The Information Society Directive of $2001^{5}$ - the major European Union horizontal instrument to have been adopted in the field of copyright - has also left intact the territorial nature of rights leading to 27 different sets of laws applying in the field of copyright and Internet-based services. This directive which aims at protecting the most important commercial rights of authors and neighbouring rights holders includes a list of optional exceptions and limitations to copyright which member states can avail of on a free basis. Almost all European Union countries compensate copyright owners by imposing a private copying levy on the sellers of copying equipment - i.e., products capable of being used for making copies, such as MP3 players, DVD players, CD players, etc. Under Article 5(b) of the Information Society Directive, member states are free to decide whether or not to include an exception to the reproduction right for private copying, provided that fair compensation is offered to the copyright owner. The principle of fair compensation is not defined in the Information Society Directive, which leads to substantially different solutions at national levels.

However, in some recent case-law the willingness of the European Court of Justice to reduce the margin of discretion of member states is obvious. In the recent Padawan preliminary ruling decision, ${ }^{6}$ the European Court of Justice was asked to analyse the compatibility of Spanish law with European Union law on the compensation for private copying. The case originated from Spanish proceedings instituted by SGAE, the national collecting society, against Padawan, a distributor of copying devices. The latter had refused to pay the former the private copying levy, arguing that the way the levy was applied was discriminatory as it applied to both private persons and professionals who purchased the equipment in question.

The different questions put to the European Court of Justice were aimed at obtaining detail on the interpretation of the principle of fair compensation. As the notion is not defined by the Information Society Directive, the European Court of Justice was faced with two alternatives: either to take the view that the absence of definition should be interpreted as implicitly giving member states the power to define it, or to take the view that the notion should be given a unitary definition within the European Union. It was argued before the European Court of Justice that as the Information Society Directive provides only for minimum harmonisation, the intention of its authors was to leave the meaning of the notion of fair compensation outside the scope of European Union law. However, the European Court of Justice did not follow this argument and held that fair compensation was an autonomous concept of European Union law which had to be interpreted in a uniform manner in all member states, irrespective of the member states' rights to choose the system of collection. ${ }^{7}$ By using its

\footnotetext{
${ }^{5}$ Directive 2001/29/EC of the European Parliament and of the Council of 22 May 2001 on the harmonisation of certain aspects of copyright and related rights in the information society, O.J.2001, L 167/10-19.

${ }^{6}$ Case C-467/08, Padawan SL v Sociedad general de Autores y Editores de Espana (SGAE), [2010] not yet reported.

${ }^{7}$ Case C-467/08, Padawan SL v Sociedad general de Autores y Editores de Espana (SGAE), [2010] not yet reported, at 32-35.
} 
theological method of interpretation, the European Court of Justice underlined that the objective of the Information Society Directive - based in particular, on what was then Article 95 EC - was to harmonise certain aspects of the law of copyright and related rights and to ensure that competition in the internal market is not distorted. This objective requires the elaboration of an autonomous concept of European Union law. The autonomous concept of European Union law is indeed not a new one in the case-law of the European Court of Justice, as it has already been stated in earlier decisions in and outside the field of copyright law. ${ }^{8}$ What is however innovative in this decision is the way how the Court of Justice, for the sake of harmonisation, is trying to minimise the margin of discretion of member states by imposing a certain number of criteria for the calculation of the fair compensation, criteria that are not included in the core articles of the Information Society Directive. According to the European Court of Justice, member states are free to define the form, detailed arrangements for financing and collection, and the level of that fair compensation. In doing so, they have to maintain a fair balance between the right holders affected by the private copying exception, to whom the compensation is owed and the persons directly or indirectly liable to pay the compensation. However - narrowing down the margin of discretion for member states - the European Court of Justice added that the level of fair compensation must be calculated on the basis of the criterion of the harm caused to authors of protected works, implicitly stating that compensation should not be perceived as a right for the copyright holder, but as an obligation for the user to repair harm.

By referring to recitals 35 and 38 of the preamble to the Information Society Directive, the European Court of Justice goes even further in its analysis by stating that possible harm should also be repaired. ${ }^{9}$ As to the person considered to be responsible for the harm, the European Court of Justice states that it should be the person who, for his private use, reproduces a protected work without seeking prior authorisation from the right holder. However, it might be practically difficult for the right holder to identify private users. Moreover, the harm which may arise from each private use, considered separately, may be minimal and may therefore not give rise to an obligation of payment under the Information Society Directive. In order to overcome these difficulties, the European Court of Justice, by adding a new mechanism not provided for in the Information Society Directive, authorises member states to adopt a system which shift the burden of compensation from the private user of the copy to the person who has the digital reproduction equipment, devices and media and who, on that basis, make that equipment available to private users or who provide copying services to them. According to the European Court of Justice, member states are free to impose

\footnotetext{
${ }^{8}$ For copyright cases: see Case C-5/08, Infopaq v. Danske Dagblades Forening where the European Court of Justice had stated earlier that "the need for uniform application of Community law and the principle of equality require that where provisions of Community law make no express reference to the law of the Member States for the purpose of determining their meaning and scope, as is the case with Article 2 of Directive 2001/29, they must normally be given an autonomous and uniform interpretation throughout the Community" (confirming Case C-245/00 SENA [2003] ECR I-1251, paragraph 23, and Case C-306/05 SGAE [2006] ECR I-11519, paragraph 31).

${ }^{9}$ Case C-467/08, Padawan SL v Sociedad general de Autores y Editores de Espana (SGAE), [2010] not yet reported, at 39.
} 
the "private copying levy" not on the private persons concerned but to those who have the digital right of reproduction equipment, devices and media. The fact that this solution seems however contrary to recital 31 of the preamble to the Information Society Directive - which stipulates that the person liable to finance fair compensation is the user of the protected subject matter - did not restrain the European Court of Justice from putting forward this argument. For the European Court of Justice, in the first place, the activity of the persons having the digital right of reproduction equipment is a factual precondition for private users to obtain copies and second, nothing prevents these persons from passing the private copy levy in the price charged for making reproduction equipment or for obtaining copies. It can therefore be concluded that the private user is the person indirectly liable to pay fair compensation. ${ }^{10}$ As a presumption of harm is enough in order to create responsibility to pay fair compensation, there is no obligation to show that private persons have in fact made private copies. It is sufficient to prove that the equipment has been made available to them. The fair compensation must however be applied in an indiscriminately manner to all types of digital reproduction equipment and devices.

By way of conclusion, in this case-law, the elaboration of an autonomous concept of European law enables the European Court of Justice to respond to a number of silences of the Information Society Directive on the private copying exception, its mechanism of payment and its elements constituting responsibility. In doing so, and to the detriment of the member states' margin of discretion, it tries to compensate for a lack of harmonization in the field of European Union copyright law. The current state of copyright law in Europe is due to a piecemeal approach to harmonisation. A solution might be to adopt soft law instruments such as recommendations, interpretative notices or communications. ${ }^{11}$ Another option could be to go for full harmonisation via a copyright regulation or the adoption of a European copyright code. ${ }^{12}$ However, the success of such a process depends on how far the European Union is ready to go in order to get rid of the territorial nature and territoriality principle.

\section{The role of the European Court of Justice in shaping the legal professional privilege as a general principle of EU law: a concept still in evolution?}

The right to legal professional privilege in the European Union derives from the national legal systems of member states and, to a lesser extent, from Articles 6(3)(c) and

\footnotetext{
${ }^{10}$ Case C-467/08, Padawan SL v Sociedad general de Autores y Editores de Espana (SGAE), [2010] not yet reported, at 46-48.

${ }^{11}$ In its study on The Recasting of copyright \& related rights for the knowledge economy prepared in 2006 at the request of the European Commission, IViR (Institute for Information law of the University of Amsterdam) concludes that in the short run, no more legislative acts are needed in the field of copyright, except where a clear need for amendment of the existing acquis can be showed.

${ }^{12} \mathrm{~A}$ step in that direction have been made by the academic members of the WITTEM group which have the goal to develop principles for a future "European Copyright Code".
} 
8 of the European Convention on Human Rights (ECHR), ${ }^{13}$ as neither the Treaties nor secondary legislation originally made any provision on this issue. There had actually been attempts to include protection of the privilege in secondary legislation concerning the application of what are now Articles 101 and 102 TFEU (ex Articles 81 and $82 \mathrm{EC}$, and Articles 85 and 86 EEC) well before the first elaboration of the principle from the European Court of Justice in the early 1980s. In fact, the first such attempt went back to the time before the adoption of the very first regulation implementing the Treaty articles on competition. In particular, the Deringer Report (which preceded the adoption of Regulation 17/62) contained a recommendation - not however, followed by the Council - whereby documents and information protected by the secret professionnel should not be disclosed. The second attempt, although concerning the extension of the privilege to in-house counsel, dates back to the legislative process bringing to the adoption of Regulation 1/2003. On that occasion, the Committee for the Economic and Monetary Affairs of the European Parliament had initially adopted an amendment whereby legal professional privilege was extended to in-house counsel. Subsequently, following strong opposition from the Commission, the amendment was rejected by the plenary of the Parliament and by the Council.

In the light of the first failed attempt by the legislature, as often happens in the European Union system, the European Court of Justice stepped in and affirmed legal professional privilege as a general principle of European Union law in the 1982 judgment in the $A M \& S$ case. $^{14}$

The year 2010 will certainly be remembered for the Judgment of the Grand Chamber of the European Court of Justice in the Akzo case. ${ }^{15}$ For many, it most probably placed the last brick in the European Union's construction of the concept of legal professional privilege in the European Union legal system. ${ }^{16}$ At first sight, the contrary cannot be affirmed as the European Court of Justice, upholding the 2007 General Court's judgment, ended a seven-year-long judicial saga by denying the extension of legal professional privilege to in-house counsel in the European Union legal system. Although the uncontroversial conclusion from the European Court of Justice in September 2010 might be seen as the last brick in the wall started building in 1982, when the $A M \& S$ case was delivered; ${ }^{17}$ that wall might not be as solid as it looks like or as it is represented. In fact, if we have a look at how the European Court of Justice has construed that privilege since the early days, we are able to see the principle has a

\footnotetext{
${ }^{13}$ The greater role assigned to the national legal systems of the member states can be inferred from the $A M \& S$ case itself, in particular from the accurate analysis of those systems carried out by Advocate General Warner and Advocate General Slynn in their Opinions to that case. The Court then concluded that the right to legal professional privilege had to be considered as one of the fundamental elements of the broader right to a fair trial, rather than an expression of the right to privacy. Therefore, it has been argued that for the sake of legal privilege, the right to privacy cannot be considered an autonomous aim. Rather it is one element necessary for the exercise of defence rights. Therefore, the need for privacy to be protected is instrumental to the effective exercise of the rights of defence. See, Gippini-Fournier [1], pp. 587, 613.

${ }^{14}$ Case 155/79, AM\&S v Commission [1982] ECR 1575.

${ }^{15}$ Case C-550/07 P, Akzo Nobel Chemicals Ltd and Akros Chemicals Ltd v Commission [2010] not yet reported.

${ }^{16}$ See, Pais Antunes [2], p. 3.

${ }^{17}$ Case 155/79, AM\&S v Commission [1982] ECR 1575.
} 
substantially flexible nature, which means changes for the future cannot be ruled out, depending on the evolution of the application of the principle, at the level of member states' legal systems, towards more common standards.

Although recently touched upon in the occasion of the Akzo case before the two instances of the European Union judicature, ${ }^{18}$ the fundamental features of legal professional privilege in European Union antitrust proceedings are still enshrined in the $A M \& S$ case. $^{19}$ It is in this latter case that the European Court of Justice affirmed the two necessary conditions for the relevance of the privilege. Firstly, correspondence has to be exchanged between lawyer and client with the objective of, and in the interests of, the latter's rights of defence; and, secondly, the correspondence must emanate from independent lawyers, that is lawyers who are not bound to the client by a relationship of employment. The European Court of Justice went even further, specifying that privilege applied to all lawyers entitled to practice in one of the European Union member states, covering written communications exchanged after the beginning of the administrative procedure before the European Commission and also those exchanged before but presenting a relationship with the object of the proceedings, namely the finding of an infringement of Articles 101 or 102 TFEU. ${ }^{20}$ As for the independence of the lawyer, this requirement was based on a conception of the lawyer's role of collaborating in the administration of justice and as being required to provide, in full independence and in the overriding interests of that cause, such legal assistance as the client needed. The counterpart to that protection was to be found in rules of professional ethics and discipline, laid down and enforced in the general interest. The European Court of Justice held that such a conception reflected legal traditions common to the member states and was also to be found in the legal order of the European Union, as showed in Article 19 of the Statute of the Court of Justice. ${ }^{21}$ Therefore, according to the Court, the requirement of independence meant the absence of any employment relationship between the lawyer and his client, regardless of his enrolment with a Bar or Law Society and the consequent professional ethical obligations to which he was subject to, like in the case at issue. ${ }^{22}$ In fact, the application of those obligations to in-house counsels may be less efficient as compared to

${ }^{18}$ Case T-125/03 and T-253/03, Akzo Nobel Chemicals Ltd and Akros Chemicals Ltd v Commission [2007] ECR II-3523; Case C-550/07 P, Akzo Nobel Chemicals Ltd and Akros Chemicals Ltd v Commission [2010] not yet reported.

${ }^{19}$ Case 155/79, AM\&S v Commission [1982] ECR 1575.

${ }^{20}$ Case 155/79, AM\&S v Commission [1982] ECR 1575, at 21 and 25. It has been argued that, by including the correspondence exchanged previous to the opening of the administrative procedure, the interpretation of the privilege given by the European Union Courts seems to go well beyond the necessary protection of the rights of defence as conceived in the jurisprudence on the ECHR. See, Gippini-Fournier [1], p. 625.

${ }^{21}$ Case C-550/07 P, Akzo Nobel Chemicals Ltd and Akros Chemicals Ltd v Commission [2010] not yet reported, at 42, confirming what previously affirmed in Case 155/79, AM\&S v Commission [1982] ECR 1575 , at 24 .

${ }^{22}$ The Court adopted a structural, or negative, concept of independence, rather than a positive one. In fact, it did not affirm that a lawyer enrolled with a Bar is independent, but that a lawyer subject to an employment contract is not independent. See, Case 155/79, AM\&S v Commission [1982] ECR 1575, at 27; Case T-125/03 and T-253/03, Akzo Nobel Chemicals Ltd and Akros Chemicals Ltd v Commission [2007] ECR II-3523, at 168; Case C-550/07 P, Akzo Nobel Chemicals Ltd and Akros Chemicals Ltd v Commission [2010] not yet reported, at 42-50, making reference to the Opinion of A.G. Kokott at 60-61. 
their application to independent lawyers. ${ }^{23}$ It was starting from this assumption that, in the Akzo case, the European Court of Justice found that the General Court did not err in holding that there was no breach of the principle of equal treatment, because in-house lawyers are in a fundamentally different position from external lawyers. ${ }^{24}$

The flexible non-definitive construction of the principle at stake has been confirmed by the European Court of Justice in acknowledging that, although the role of in-house lawyers and the protection of the correspondence with them under legal professional privilege was relatively more common in 2004 (when the Akzo case was handed down at first instance) than in 1982, it was nevertheless impossible to identify tendencies which were uniform or had clear majority support in the laws of the member states. ${ }^{25}$ The European Court of Justice, therefore, concluded that no predominant trend towards the protection under legal professional privilege of communications within a company or group with in-house lawyers could be discerned in the legal systems of the 27 member states of the European Union. ${ }^{26}$ In upholding the analysis carried out in the case at first instance, the European Court of Justice agreed on the refusal to widen the personal scope of the privilege, notwithstanding the applicants' argument that, considering the lack of a uniform tendency at national level, European Union law could set legal standards for the protection of the rights of defence at a level higher than those set in certain national legal orders. ${ }^{27}$

To conclude, the Akzo case illustrates the substantially flexible and evolutionary nature of legal professional privilege as interpreted in the European Union legal system. In consequence, it cannot be affirmed that, once the scope of that principle is established, it will be immune from future developments. Regardless of the quite "static" evolution of legal professional privilege in the European Union system in the last thirty years, the General Court, supported by the European Court of Justice in the appeal case, did however identify some sort of evolution in the protection of the privilege, thus leaving an open door for the future.

\footnotetext{
${ }^{23} \mathrm{~A}$ tribunal can prohibit an independent lawyer to practice. Moreover, the latter can withdraw from his mandate if he discovers an illegal action undertaken by his client. On the contrary, it does not seem that an in-house counsel can withdraw from his mandate without losing his job.

${ }^{24}$ Case C-550/07 P, Akzo Nobel Chemicals Ltd and Akros Chemicals Ltd v Commission [2010] not yet reported, at 58-59.

${ }^{25}$ In drawing such conclusions, the Court of Justice relied on the comparative examination conducted by the General Court showing that a large number of member states still exclude correspondence with in-house lawyers from protection under legal professional privilege. Furthermore, a considerable number of member states (i.e. France and Italy) do not allow in-house lawyers to be admitted to the Bar or Law Society, therefore, not recognising them as having the same status as lawyers established in private practice. See, Case C-550/07 P, Akzo Nobel Chemicals Ltd and Akros Chemicals Ltd v Commission [2010] not yet reported, at 72 .

${ }^{26}$ Case C-550/07 P, Akzo Nobel Chemicals Ltd and Akros Chemicals Ltd v Commission [2010] not yet reported, at 74 .

${ }^{27}$ Case C-550/07 P, Akzo Nobel Chemicals Ltd and Akros Chemicals Ltd v Commission [2010] not yet reported, at 66.
} 


\section{Conclusion}

In the light of the foregoing, it is clear that the European Court of Justice adopted a similar, but not identical, approach in construing, on the one hand, the principle of fair compensation with regard to the Information Society Directive and, on the other hand, the principle of legal professional privilege with regards to competition law proceedings - in both cases in order to fill gaps in the European Union legal system. In the first case, the European Court of Justice affirmed that the principle of fair compensation was an autonomous concept of European Union law to be interpreted uniformly across the European Union, because the relevant European Union measures did not make any express reference to the law of the member states for the determination of the meaning and the scope of the relevant principle. In the second one, the European Court of Justice tried to construe an autonomous European Union concept of legal professional privilege, going even beyond the protection granted by the ECHR, although it arrived at that result making reference to the traditions of the member states and opting for a sort of majority criterion in determining the scope of the principle, thus leaving room for possible future changes depending on the stability of that majority.

\section{References}

1. Gippini-Fournier, E.: Legal professional privilege in competition proceedings before the European Commission: beyond the cursory glance. In: Hawk, B.E. (ed.) International Antitrust Law and Policy, Annual Proceedings of the Fordham Corporate Law Institute (2005)

2. Pais Antunes, L.: Just another brick in the wall: communications with in-house lawyers remain unprotected by legal privilege at the European Union level. In: J. Eur. Compet. Law Pract. (1) (2011)

3. Walter, M., Lewinski, S.V.: European Copyright Law: A Commentary. Oxford University Press, London (2010) 